研究

\title{
メカニカルアロイングにより合成した $\mathrm{SnO}_{2}$ 粒子分散 $\mathrm{Ag}$ 複合粉末粒子の 熱処理における分散相と基地間の分離現象
}

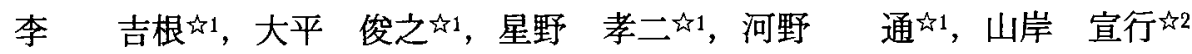

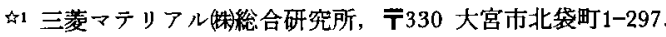 \\ 山2 東富士製作所, 于410-11 裙野市千福46-1.
}

\section{Separaration Phenomenon between Dispersion Phase and Matrix of Mechanical Alloyed $\mathrm{SnO}_{2}$ Particle Dispersed Ag Composite Powder Particles during Heat Treatment}

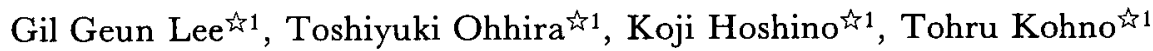 \\ and Nobuyuki Yamagishi ${ }^{\natural 2}$ \\ 41 Central Research Institute, Mitsubishi Materials Corp., 1-297 Kitabukuro-cho, Omiya 330. \\ म2 Higashifuji MFG Co. Ltd., 46-1 Sempuku, Susono 410-11.
}

Received February 9, 1996

\begin{abstract}
SYNOPSIS
Powder pre mixture of $\mathrm{SnO}_{2}$ and silver was tumbler-ball milled to investigate the influence of milling effect on the phase separation between oxide phase and matrix phase during heat treatment of mechanical alloyed oxide dispersided metal matrix composite particles. The milled powder for period milling time was heat treated in the air atmosphere, and the microstructure and phase formation during heat treatment were monitored by X-ray diffraction analysis(XRD), optical microscopy, SEM, EPMA and DTA. The cross section area ratio of the pure silver to total particle of the heat treated composite particles was measured with heat treatment temperature as function of milling time and volume fraction of $\mathrm{SnO}_{2}$, using image analysis system. The separation between dispersion phase, $\mathrm{SnO}_{2}$, and matrix phase, silver, was occurred when heat treated over the critical temperature of the composite particle milled over the period milling time. It considered that the separation phenomenon between dispersion phase and matrix phase during heat treatment was caused by mass transfer started by the release of internal energy which stored in the composite particle during mechanical alloying.
\end{abstract}

KEY WORDS

mechanical alloying, silver, composite particle, nano structure, phase separation, heat treatment, milling effect

\section{1 緒 言}

メカニカルアロイング法1は固相状態で合金形成 成分の超微細均一混合，合金化などを行うため，合 金構成成分に依存せず，微細均一な組織を持つ複合 粒子2)，金属間化合物粒子3)などの合成が可能であ る、特にメカニカルアロイングの一つの特徴である 非平衡プロセスの特徴を生かして，準安定な金属間 化合物粒子(4)，アモルファス粒子(5)どの合成が可能 となり, 従来の構造材料としての材料機能以外の
様々な機能を要する材料分野へのその応用が期待さ れている.

一般的にメカニカルアロイング法で合成した粒子 分散複合材料は，他の製造法で合成したものより微 細均一な構造を持ち，熱的安定性が良いことが知ら れている2). しかし，高橋ら方はメカニカルアロイン グにより合成した酸化物粒子分散 $\mathrm{Cu}$ 複合粉末粒子を 熱処理すると酸化物とCuが分離を起こし，熱的安定 性が不十分であることを報告している，また，著者 
ら7もメカニカルアロイングにより合成した $\mathrm{SnO}_{2} /$ $\mathrm{Ag}$ 複合粉末粒子においても同様な分離現象が生じる ことを報告し，このような分離現象が生じる複合粉 末の固化成形法として物質移動が生じる固化成形法 の一つである押出しによる固化成形を提案し，熱的 安定性が良い微細均一な棈造を持つSnO2/Ag複合材 料の合成の可能性を示唆した。また，新見ら日)はメ カニカルアロイングにより合成した酸化物分散 $\mathrm{Cu}$ 複 合粉末の焼結合成時，分散相と基地間の分離により 焼結性が向上し，複合材料の機械的特性が向上する ことを報告している。このように酸化物分散複合粉 末粒子の熱処理における分散相と基地間の分離現象 は，メカニカルアロイング法によって酸化物分散 $\mathrm{Cu}, \mathrm{Ag}$ 基複合材料を合成する時一般的に観察され るものであり，メカニカルアロイング法によりこれ らの機能性複合材料を効率良く製造するためには, 分離現象の詳細な検討が不可欠である。このような 分離現象が酸化物と基地間の濡れ性およびメカ二カ ルアロイング中に混入された不純物などに依存する ことを示唆する実験結果9,10)が報告されているが，ま だその詳細については知られていない. 特にメカニ カルアロイング法で合成した粉末粒子の特性がミリ ング条件によって異なる11,12)ことから, 分散相と基 地間の分離現象にはミリング効果が重要な役割を果 たしていると考えられるが, 分離現象にミリング効 果の影響を取り入れた報告例は見当たらない.

本研究はメカニカルアロイングにより合成した粒 子分散複合粉末粒子の熱処理における分散相と基地 相間の分離現象の解明を目的としており，本論文で は分離現象に及ばすミリング効果の影響について報 告する。

\section{2 実験方法}

メカニカルアロイングには純度 $99.9 \%$ O SnO2粉末 (粒径：15mm以下) と純度 $99.99 \% の \mathrm{Ag}$ 粉末（粒 径：75mm以下）を用いた. $\mathrm{SnO} / \mathrm{Ag}$ 体積の比が1/ 10，1/5，3/10，2/5になるように混合し，それぞれ の混合粉を乾式条件と湿式条件で最大 $500 \mathrm{~h}$ 転動ボー ルミリングした，乾式ミリングには大気雾囲気を， 湿式ミリングには溶媒としてエタノールを用いた。

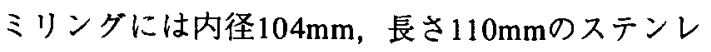
ス鋼（SUS304）製ミル容器と直径6.35mmのステン レス鋼（SUS304）製ボールを用いた。粉末/ボール 重量比は1/12.5, 溶媒/粉末重量比を $1 / 2 に 一$ 定にし
た。所定時間ミリングした後ミリング粉末を1073K まで大気中で熱処理し, 熱処理前後の粉末のX線回 折, 内部組織観察, EPMA, DTAおよびXPS分析を 行った. 粉末粒子の内部組織観察は，粉末を樹脂に 埋め込んで断面研磨試料を作製し，画像解析装置を 用いて行った。

\section{1 分離現象の観察}

\section{3 結果および考察}

Fig.1に湿式条件で10h，20h，50h，100hミリング したミリング粉末粒子を973Kで2h大気中で熱処理 した時の熱処理前後の粒子断面の光学顕微鏡写真を 示す. 写真から分かるようにミリング50h以後には ラメラ構造が消失し, 微細均一な組織になることが 分かる。また，熱処理前にはSnO2が均一に分散した 内部組織を持っているが，熟処理によってミリング $50 \mathrm{~h}$ 以後の複合粒子の表面部に白い層が現われ，不 均一な組織になることが分かる。この白い部分は EPMA分析結果, 純Ag（SnO2はほとんど検出され ない）相であった。このようにメカニカルアロイン グによって合成したSnO2/Ag複合粉末粒子は熱処理 によって分散相であるSnO2 と基地相である Ag間の 分離が生じることが分かる. また，ミリング50hよ りミリング100hの方がAg層が顕著に現われること が分かる. Fig.2に湿式条件で100hミリングした粉末 を1073Kまで各温度で1 $\mathrm{min}$ 熱処理した時の各温度に おける粉末粒子表面のSEM観察写真を示す. 写真か ら分かるようにミリング直後の粒子表面はナノサイ ズのSnO2粒子が Ag基地中に均一に分散している が，熱処理温度673Kにミリング粒子の表面に局部 的に約 $1 \mu \mathrm{m}$ サイズの純 $\mathrm{Ag}$ 粒子がミリング複合粒子の 内部から染み出すように形成され，温度の増加とと もに純 $\mathrm{Ag}$ 粒子の数が增加し, 次第に純 $\mathrm{Ag}$ 粒子同士 が合体してAg層がミリング粒子表面を覆って行くこ とが分かる。ミリング粒子表面に形成されたAg粒子 サイズの温度増加にともなう大きな増加は認められ なかった。このようにある時間以上のメカニカルア ロイングによって合成した $\mathrm{SnO} 2 / \mathrm{Ag}$ 複合粒子を熱処 理するとある温度以上から $\mathrm{SnO} 2$ 分散相と $\mathrm{Ag}$ 基地間 の分離が徐々に起こることが分かる.

Fig.3に20h，50h，100hミリングした粉末の熱分 析結果を示す，図から分かるようにミリング時間の 增加にともなう熱分析結果の大きな違いは認められ ないことが分かる. ミリング時間の增加とともにAg 


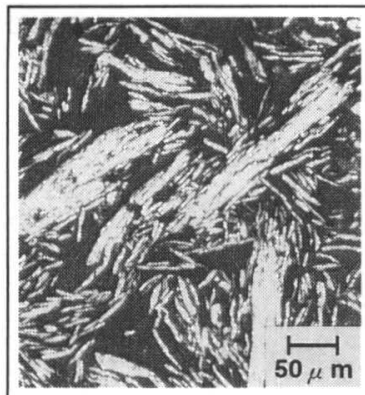

(a)

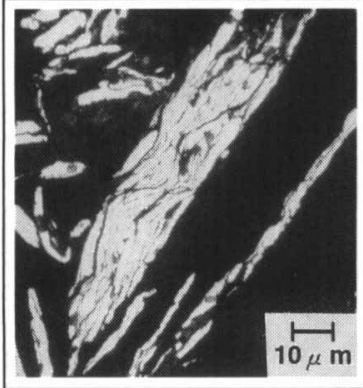

(e)
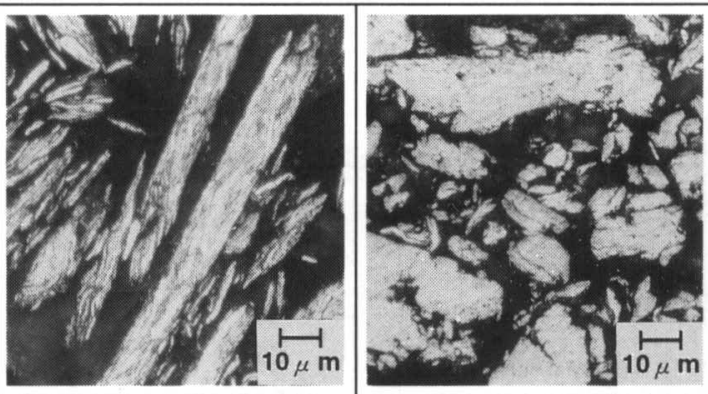

(c)

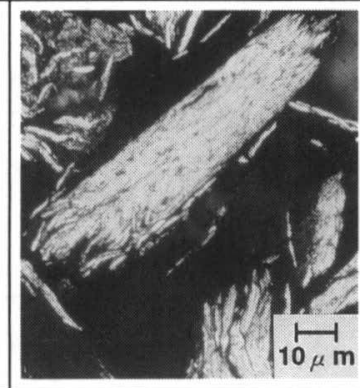

(f)

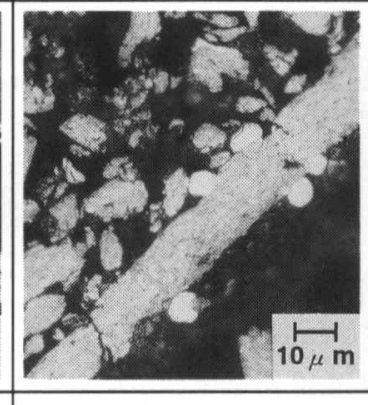

(g)

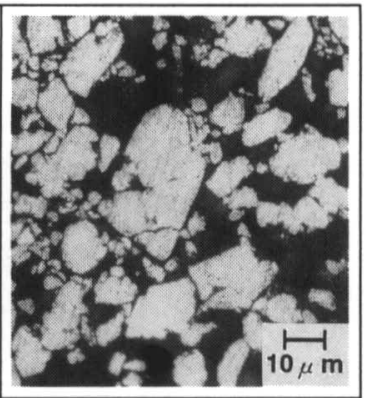

(d)

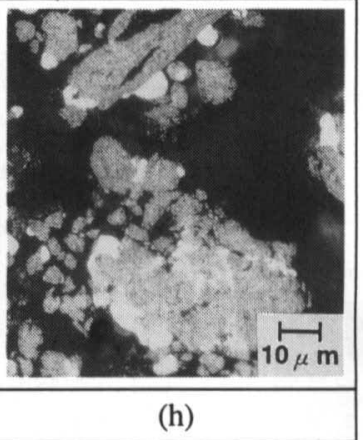

Fig.1 Optical micrographs of cross sections of milled and heat treated 20vol.\%SnO2/Ag composite particles with milling times (a)(e) $10 \mathrm{~h},(\mathrm{~b})(\mathrm{f}) 20 \mathrm{~h},(\mathrm{c})(\mathrm{g}) 50 \mathrm{~h}$ and (d)(h) $100 \mathrm{~h}$. Heat treatment was carried out at $973 \mathrm{~K}$ for $2 \mathrm{~h}$ in the air atmosphere after milled for period milling time.(Upper: as-milled particle, lower: heat treated particle.)

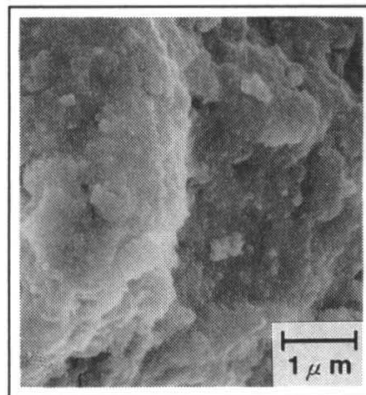

(a)

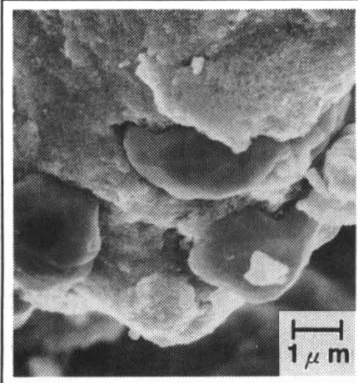

(e)

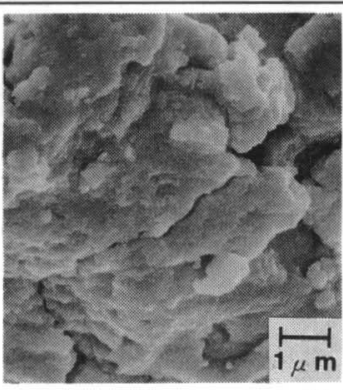

(b)

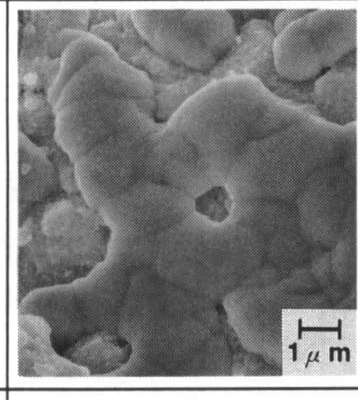

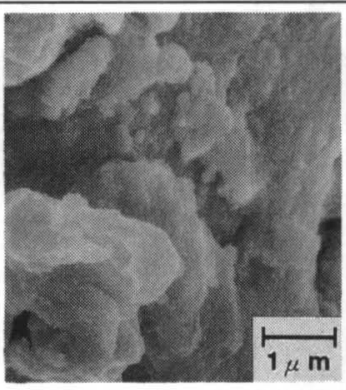

(c)

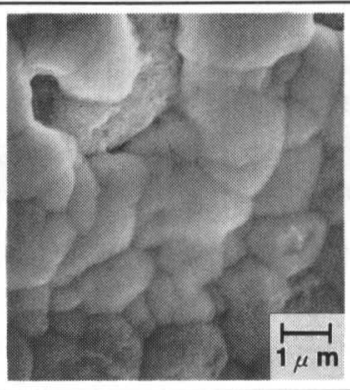

(g)

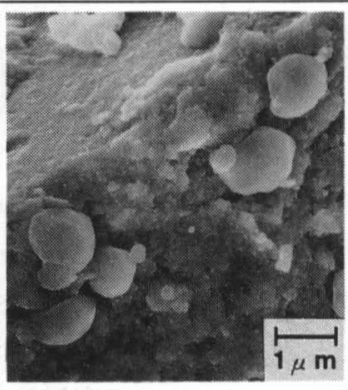

(d)

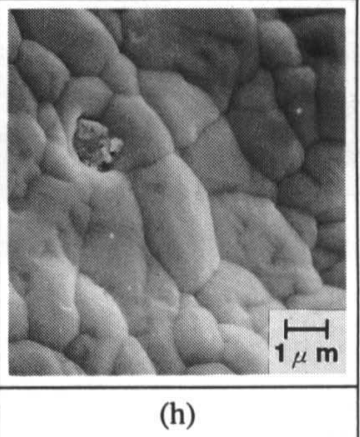

Fig.2 Scanning electron micrographs of heat treated $20 \mathrm{vol} . \% \mathrm{SnO} / \mathrm{Ag}$ composite particle surface with heat treatment temperaturs (a)as-milled, (b)473K, (c)573K, (d)673K, (e)773K, (f)873K, (g)973K and (h)1073K. Composite particles were pre-milled for $100 \mathrm{~h}$ before heat treatment. 


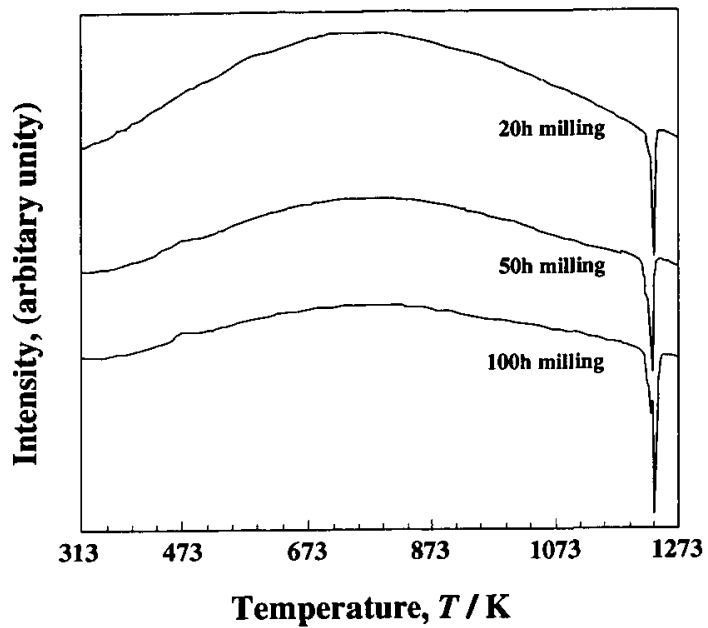

Fig. 3 Changes of DTA curve of $20 \mathrm{vol} . \% \mathrm{SnO} 2 / \mathrm{Ag}$ composite powder particle with various milling times.

の溶融を示す $1233 \mathrm{~K} の$ 吸熱ピークが低温側に移動す る傾向を示すが，これはミリング効果によるものと 思われる。また，ミリング時間の増加とともに 473K付近に発熱ピークが現れるが,これは溶媒と して用いたエタノールによる残留Cの影響によるも のと考えられる．特に100hミリングした粉末の場 合, 673Kから SnO2 と Agの分離が観察される（Fig.2 参照）が，673K以上の温度においても発熱あるい は吸熱ピークが観察されないことから，SnO2分散相 と $\mathrm{Ag}$ 基地間の分離には急激な熱の出入を随伴しない ことが分かる.Fig.4に100hミリングした粉末の熱処 理前後のX線回折ピークを示す．図から分かるよう に熱処理にともなう $\mathrm{Ag} と \mathrm{SnO}_{2}$ の回折ピーク幅の減 少およびピーク強度の増加以外は観察されず，㷱処 理による相変化, 新たな相形成などは起こらないこ とが分かる。このように熱処理による分散相と基地 間の分離は，構成成分の物理·化学的な大きな変化 を随伴しない単純な物質移動によるものと考えられ る.また, 物質移動が $673 \mathrm{~K}$ と言う比較的低温で起 こることからこのような物質移動は高温で観察され る分散相と基地間の悪い濡れ性をきっかけとするも のとは異なることが推定される.

このような物質移動を詳細に検討するため, 乾式 条件でミリングを行って, 平均粒径 $1.5 \mathrm{~mm}$ の粗大等 軸形複合粒子を合成し，これらの粒子の熱処理にお ける分散相と基地相の物質移動を検討した。粗大な 等軸形複合粒子を用いたのは, ミリング中のミリン グ効果が粒子の内部より表面部に集中する(3)ことに

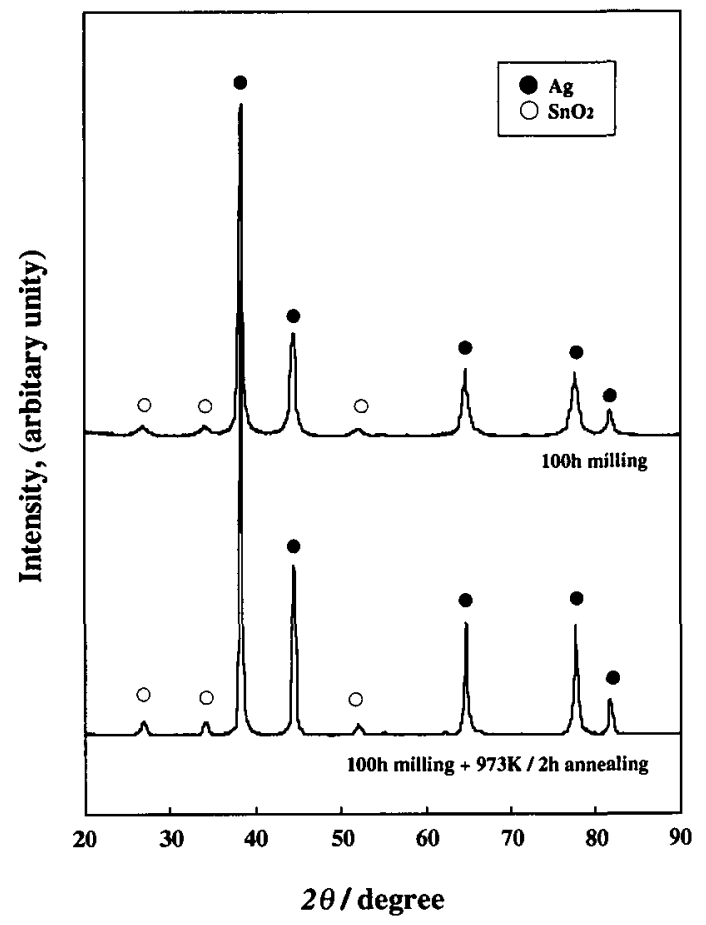

Fig. $4 \mathrm{X}$-ray diffraction patterns of as-milled and heat treated $20 \mathrm{vol} . \% \mathrm{SnO} / \mathrm{Ag}$ composite powder particle.

着目し，このような物質移動に及ぼすミリング効果 の影響を検討するためである. Fig.5に熱処理温度に よる粒子断面の光学顕微鏡写真を示す. 写真から分 かるように低温では粒子の表面部のみにAg層が形成 されるが, 熱処理温度の増加とともに粒子の内部に も Ag層が形成されることが分かる.これは熱処理に よる物質移動が複合粒子の内部より表面部で起こり 易いことを示唆し，ミリング効果が物質移動に影響 していることを示す.すなわち熱処理によるSnO2分 散相と $\mathrm{Ag}$ 基地間の分離には, 濡れ性以外にもミリン グ効果が大きな役割を果たしていることが推定され る.

\section{2 ミリング効果の影響}

熱処理にともなう分散相と基地間の分離現象に及 ほすすミリング効果の影䇒を検討するため，画像解析 装置を用いて粒子断面の全面積に対する Ag層の面積 の割合（Ag層面積比率, Ag layer area ratio）を測定 した. Fig.6に所定時間ミリングした20vol.\%SnO2/ $\mathrm{Ag}$ 複合粉末を各温度で1 min熱処理した場合の $\mathrm{Ag}$ 層 面積比率の熱処理温度による変化を示す. 図から分 かるように熱処理温度の増加と，ミリング時間の増 


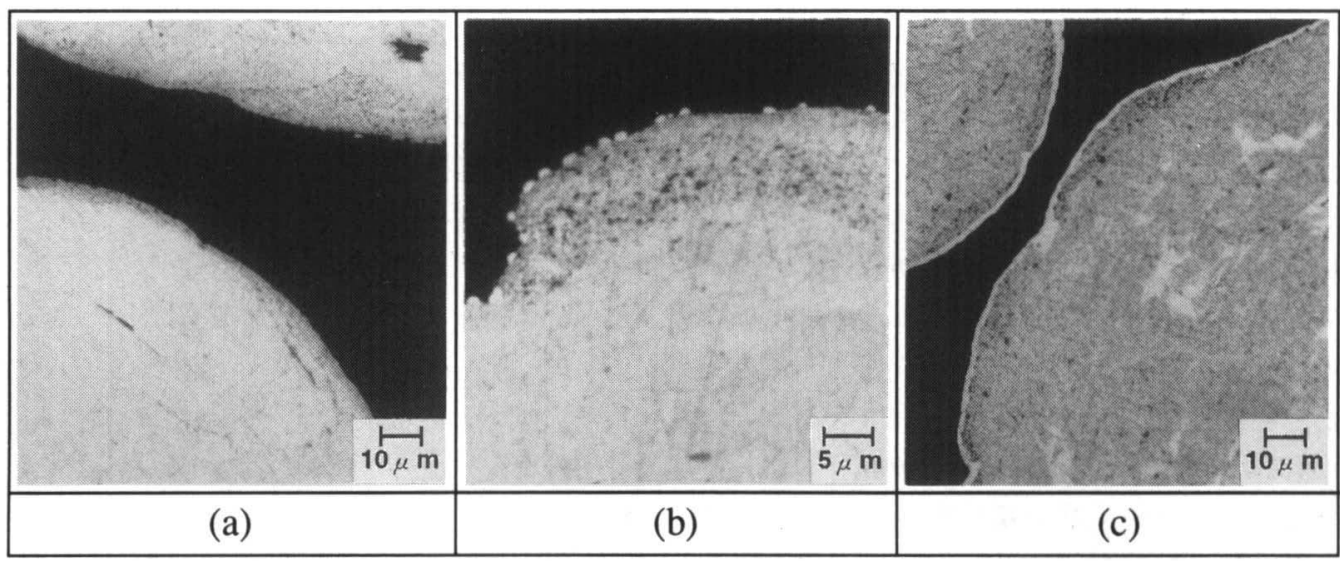

Fig.5 Optical micrographs of cross section of dry milled 20vol.\%SnO2/Ag composite particle with heat treatment temperatures (a)as-milled, (b) $573 \mathrm{~K}$ and $973 \mathrm{~K}$. Composite particles were dry milled for $200 \mathrm{~h}$ before heat treatment.

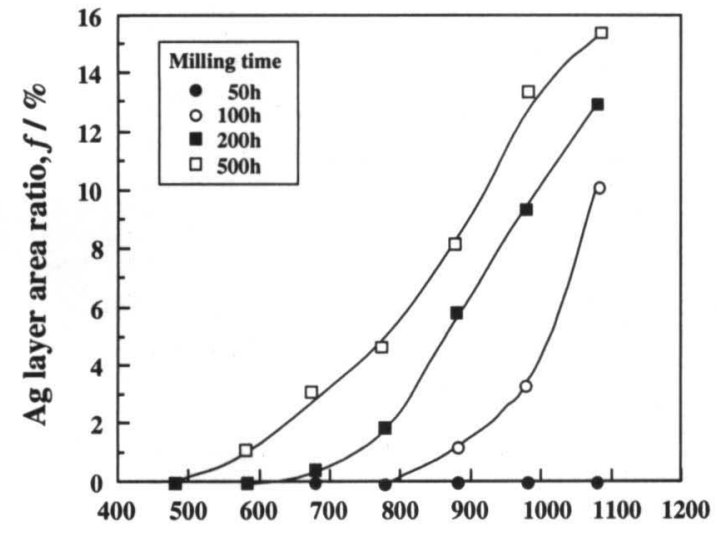

Heat treatment temperature, $T$ / K

Fig.6 Changes of $\mathrm{Ag}$ layer area ratio of $20 \mathrm{vol} \% \mathrm{SnO} / \mathrm{Ag}$ composite particles with heat treatment temperature for various milling times.

加とともにAg層面積比率が増加することが分かる.

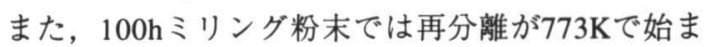

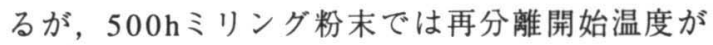
473Kまで低下し，ミリング時間の増加とともに分 離開始温度が低下することが分かる。 また，ミリン グ50h以前の粉末は1073Kまで熱処理しても分離が 生じないことが分かる. 同じ熱処理温度においても ミリング時間の増加とともにAg層面積比率が増加す ることは, ミリング時間の増加とともに物質移動の 駆動力が大きくなることを意味する.メカニカルア ロイング中にはミリング時間の増加とともに構成成 分の微細均一混合, 分解, 合金化, 格子欠陥の導 入, 不純物混入などが生じる.しかし，前述したよ うにミリング時間の増加にともなう $\mathrm{SnO} 2$ と $\mathrm{Ag}$ の化
学的な大きな変化が認められないことから，ミリン グ時間の増加にともなう $\mathrm{Ag}$ 層面積比率の増加は, ミ リング時間の増加にともなう $\mathrm{SnO} 2$ と $\mathrm{Ag}$ の微細均一 混合, 格子欠陥の導入, 不純物混入などによるもの と推定せれる. Table1にミリング粉末のミリング時 間による成分分析結果を示す．表から分かるように ミリング時間の増加とともに不純物である $\mathrm{Fe}, \mathrm{C}$, Oの量が増加することが分かる．高橋ら ${ }^{10}$ は分離現

Table1 Chemical compositions of mechanical alloyed $20 \mathrm{vol} . \% \mathrm{SnO} 2 / \mathrm{Ag}$ composite powder for various milling times.

\begin{tabular}{c|c|c|c|c|c}
\hline \hline \multirow{2}{*}{ Milling time } & \multicolumn{5}{|c}{ Element (wt.\%) } \\
\cline { 2 - 6 } & $\mathrm{Fe}$ & $\mathrm{O}$ & $\mathrm{C}$ & $\mathrm{Sn}$ & $\mathrm{Ag}$ \\
\hline $20 \mathrm{~h}$ & 0.06 & 3.0 & 0.05 & 9.75 & 87.14 \\
$50 \mathrm{~h}$ & 0.13 & 3.1 & 0.06 & 9.68 & 87.03 \\
$100 \mathrm{~h}$ & 0.24 & 3.3 & 0.11 & 9.71 & 86.64 \\
$200 \mathrm{~h}$ & 0.35 & 3.5 & 0.15 & 9.64 & 86.36 \\
\hline
\end{tabular}

象が基地金属中の不純物である○によることを示唆 しているが, 新見ら ${ }^{8}$ は不純物である○の量が増加す ると酸化物と基地金属間の濡れ性が改善され分離が 起こりにくいことを報告している．本実験では○の 増加とともにAg層面積比率が増加し新見らの報告と は異なる。このようなことから分散相と基地間の分 離現象の駆動力としては, 不純物の混入によるもの より構成成分の微細均一混合, 格子欠陥の導入など による複合粒子内部の内部エネルギーの増加が大き な役割を果たしていると考えられる．すなわち熱処 
理にともなう分散相と基地間の分離は，ミリング効 果によって粒子内部に蓄積された内部エネルギーの 解放をきっかけとする物質移動である．この物質移 動には濡れ性，不純物なども影響していると考えら れるが，今後詳細な検討が必要である．また，ミリ ング50h以後から分離が生じることから分離に要す る臨界条件（分散相のサイズ，基地の結㿟粒サイ ズ，界面エネルギー，ひずみなど）があると考えら れるが，その詳細については検討中である.

Fig.7に240hミリングした粉末を1073K，1173Kで $1 \mathrm{~min}$ 熱処理した時のAg層面積比率のSnO2体積分率 による変化を示す．図から分かるようにAg層面積比 率はSnO2体積分率の増加とともに増加し, $\mathrm{SnO}_{2}$ 体 積分率 $20 \%$ で最大値を示した後減少することが分か る。これはSnO2量の増加にともなう熱的安定性の向

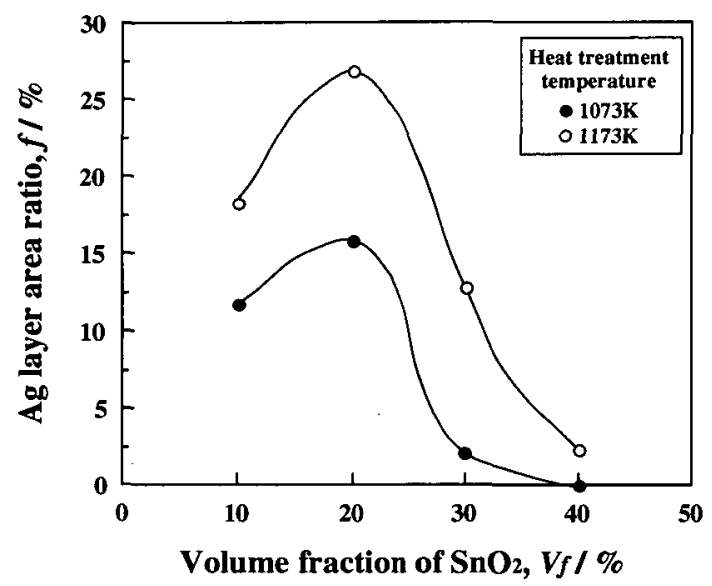

Fig.7 Changes of $\mathrm{Ag}$ layer area ratio of $\mathrm{SnO} / \mathrm{Ag}$ composite particles with volume fraction of $\mathrm{SnO} 2$ for various heat treatment temperatures.

上にもよるが，主にSnO2量の差にともなうミリング 効果の差によるものと考えられる。すなわちSnO2体 積分率20\%以下ではSnO2の微細均一化が十分に達成 され， $\mathrm{SnO}_{2}$ 体積分率の増加とともに粒子内部の内部 エネルギーが増加する．しかし， $\mathrm{SnO}_{2}$ 体積分率 $20 \%$ 以上では本ミリング条件ではSnO2の微細均一化が十 分に達成されず， $\mathrm{SnO}_{2}$ 体積分率の増加とともに粗大 な $\mathrm{SnO} 2$ やSnO2凝集体が存在し, 複合粒子内部の内 部エネルギーはそれほど增加しなかったものと考え
られる.このようにメカニカルアロイングによって 合成したSnO2 $/ \mathrm{Ag}$ 複合粒子の熱処理における分散相 と基地間の分離には，ミリング効果が大きな役割を 果たしていることが分かる。

\section{4 結 論}

メカニカルアロイングにより合成したSnO2/ $\mathrm{Ag}$ 複 合粉末粒子の熱処理に㧍ける分散相 $(\mathrm{SnO} 2)$ と基地 $(\mathrm{Ag})$ 間の分離現象について検討し，次のような結 論を得た。

1)所定時閒以上ミリングした $\mathrm{SnO} 2 / \mathrm{Ag}$ 複合粉末粒子 を所定温度以上で熱処理すると分散相である

$\mathrm{SnO}_{2}$ と基地相である $\mathrm{Ag}$ 間の分離が起こる.

2)分離現象はミリング条件（ミリング時間，分散物 体積分率）と熱処理温度に依存する。

3)このような分散相と基地間の分離は, ミリング中 にミリング効果によって複合粒子内部に蓄積され た内部エネルギーの熱処理時の解放をきっかけと する物質移動によるものと考えられる。

\section{文 献}

1) J.S.Benjamin: Metall. Trans., 1(1970), 2943.

2) 高橋輝男: 金属, 65(11)(1995), 33.

3) G.H.Fair and J.V.Wood: Powder Metallurgy, 36(2)(1993), 123.

4) 福永俊晴, 水谷宇一郎: 金属, 65(11)(1995), 25.

5) 那順稔雄: 金属, 65(11)(1995), 25.

6) 高橋輝男, 橋本雍彦, 香山滉一郎: 粉体および粉末 治金, 36(4)(1989), 66 .

7) 李吉根, 大平俊之, 星野孝二, 河野通, 山岸宣行: 粉 体揖よび粉末治金, 投稿中.

8) 新見義郎, 是川宏, 岩津修: 粉体および粉末治金,

34(6)(1987), 30.

9) 高橋輝男: 粉体および粉末治金, 39(7)(1992), 529.

10) 高橋輝男, 橋詰源蔵, 橋本雍彦, 香山滉一郎, 鈴木 建次: 日本金属学会秋期大会シンポジウム講演 予稿, 11月(1988), 189.

11) E.Gaffet: Mater. Sci. Eng., A132(1991), 181.

12) C.H.Lee, T.Fukunaga and U.Mizutani: Mater. Sci. Eng., A134(1991), 1334.

13) 斎藤文良: 資源と素材, 111(8)(1995), 515. 